\title{
Rural Infrastructure and Cropping Intensity in Odisha
}

\author{
Chittaranjan Nayak \\ Lecturer in Economics, Ravenshaw University, Cuttack, India
}

\begin{abstract}
Cropping intensity is important at least on two grounds. One; it ensures adequate food availability for the growing population and two; it results in higher earnings for farmers, given their size of land holdings. Now question arises that how can we enhance cropping intensity? There are some possible answers, viz. land consolidation, tenancy reforms, irrigation, credit, etc. The present study intends to verify the role of rural infrastructure in raising cropping intensity. The investigation has been done with help of district level secondary data from the state of Odisha by incorporating eleven items under infrastructure. These items are sub-grouped into physical, social and financial infrastructure. A composite index namely Rural Infrastructure Index (RII) has been prepared by using the method of Principal Components Analysis and simple regression technique is used to examine the impact of infrastructure on cropping intensity.

The study observes that there exists regional disparity in the stock of rural infrastructure in all the three forms. The coastal region of the state is ahead in all the three categories of infrastructure, albeit with some exceptions. The southern Odisha, mostly comprising the underdeveloped Kalahandi-Bolangir-Koraput (KBK) is still the most backward region of the state. However, as regards cropping intensity, the story is not the same.
\end{abstract}

Keywords: cropping intensity, Odisha, principal component analysis, rural infrastructure index, backward regression

JEL Code: O18, P25, Q18, R11, R12

\section{Introduction}

Rural infrastructure is considered to be a critical factor for growth of rural economy. The India Rural Infrastructure Report 2003 argues that development of rural infrastructure has a five-fold impact on the economy, viz. (i) creating better access to employment and providing further earning opportunities, (ii) increasing production efficiency, (iii) creating access to previously inaccessible commodities and services, (iv) time saving which can be better utilised in productive activities, and (v) better health and physical condition of the rural population. Question arises how does rural infrastructure increase efficiency in production? Among others, one possible explanation may be that rural infrastructure is supposed to increase cropping intensity. Cropping intensity is important at least on two grounds. On the one hand, it ensures adequate food availability for the growing population and on the other hand it results in higher earnings for farmers, given their size of land holdings. However, apart from infrastructure, geo-climatic conditions, quality of human resource, demand for agricultural produce, private capital stock, etc may be considered as important determinants of cropping intensity. The present study intends to verify if infrastructure plays a role in raising cropping intensity. The study district-level secondary data of Odisha, an east Indian state where over 80 percent of people live in rural area and agriculture is the prime source of livelihood ${ }^{1}$.

Coming to literature, although there is no dearth of studies on impact of rural infrastructure on agricultural growth (for a discussion please see Nayak 2008), very few studies have analysed its impact on cropping intensity. A study by the International Fund for Agricultural Development in Bangladesh, finds the high incidence of poverty is attributed in part to low cropping intensity, since the area remains under water for about five to six months during the year. Undeveloped roads also contribute to the poverty of the area (IFAD 2008). The Asian Development Bank observes that rural infrastructure has increased cropping intensity in Vietnam from 150 to 175 (ADB 2010). The NABARD Occasional Paper 'Infrastructure for Agricultural Development', 2010 has also found that the "Economic impact of Rural Roads and Bridges projects was observed in terms of increase in land prices, prices of agriculture produce and cropping intensity, shift in acreage towards cash crops, employment generation, allied activities, etc. Increase in crop yield was 4-10 per cent for paddy, 3-8 per cent for wheat and 10-20 per cent for sugarcane" (Sangwan 2010). Although the revelation of the studies is clear, yet the present study does some value addition by measuring rural infrastructure in a more objective manner before examining its impact on cropping intensity in the state of Odisha.

\footnotetext{
${ }^{1}$ The name of the state has been changed from Orissa to Odisha in March 2011.
} 


\section{Data And Methodology}

The present study is a cross-section study based on secondary data. Data have been collected from different published sources like Statistical Abstract of Orissa, 2002 \& 2005; different issues of Economic Survey, Government of Orissa; Agricultural Census, of Orissa, 2005; District Statistical Hand Books of all the districts of the state for different years, Primary Census Abstract (Census of India, 2001-Orissa). Cropping intensity is defined as the ratio of gross cropped area (GCA) to net sown area (NSA). Rural Infrastructure has been categorized into three broad groups, viz. Physical, Social and Financial infrastructure. Items in each category have been selected on the basis of backward regression. The details of finally selected items in each category of infrastructure have been explained in Table 1.

Since the units of measurement of the selected factors are different, they give rise to problems of aggregation. So the items have been normalized to make them unit-free. After that, I have prepared three separate indices, viz. physical infrastructure index (PII), social infrastructure index (SII), and financial infrastructure index (FII), district-wise by using the Principal Component Analysis (PCA) ${ }^{2}$. These three indices again been combined to find the overall rural infrastructure index (RII). The number of principal components have been finalised on the basis of Eigen value (higher than 1) and the Bartlett Criterion. I have done backward regression and PCA by using software SPSS.

The infrastructure index is a linear combination of the unit free values of the individual factors such that

$$
\text { Index }_{\mathrm{i}}=\Sigma \mathrm{a}_{1 \mathrm{k}} \mathrm{X}_{\mathrm{ki}}
$$

where Index $x_{i}$ index of the $i^{\text {th }}$ district, $\mathrm{a}_{1 \mathrm{k}}=$ the loading or the weight of the $\mathrm{k}^{\text {th }}$ factor in the first principal component and $\mathrm{X}_{\mathrm{ki}}=$ unit free value of the $\mathrm{k}^{\text {th }}$ factor for the $\mathrm{i}^{\text {th }}$ district.

The effect of rural infrastructure on cropping intensity has been studied by the following linear model.

CRPNGINT $_{i}=\beta_{\mathrm{o}}+\beta_{1}$ RII $_{i}+\mathrm{u}_{\mathrm{i}}$

where $\mathrm{i}$ represents $\mathrm{i}^{\text {th }}$ district, $\beta_{1}$ is the slope coefficient showing the partial effect of rural infrastructure index on cropping intensity and $u$ the error term. The dependent variable has also been regressed on PII, SII and FII separately. It is noteworthy here that the study observed existence of multicollinearity among the three categories of rural infrastructure. So, instead of fitting multi-variable linear regression model, I have fitted twovariable linear regression model.

\section{Results And Discussion}

On the basis of the PCA, the first principal components for each category of infrastructure satisfied the Bartlett criterion. Accordingly the indexes have been prepared as follows:

$$
\begin{aligned}
& \text { PII }=.684 \text { PGIA+ } .957 \text { PHHELCT+ }(-) .0764 \text { RURDEN+. } 877 \text { PHHTELCN } \\
& \text { SII }=0.843 \text { RURALIT+ (-) 0.734 BDHOSP+0.442 PGDHOUSE+0.909 PHHLATRN } \\
& \text { FII }=0.04907 \text { BNKSER+0.859 AGCREDIT+0.857 MKTGSOC } \\
& \text { RII }=0.951 \text { PII }+0.920 \text { SII }+0.863 \text { FII }
\end{aligned}
$$

\section{District-wise ranking}

The scores of individual districts in different indices of infrastructure are present in Table 2. As per the level of development of rural infrastructure, the thirty districts of the state have been ranked as per each category of infrastructure and cropping intensity (Table 3 ).

The study gets some interesting observations. Most of the coastal districts of the state rank in the top ten- both in terms of RII and CRPNGINT (please see maps 1 and 2). Surprisingly the districts Balasore and Bhadrak, which belong to the coastal plain of Odisha, rank in the low CRPNGINT districts. Is irrigation the factor which makes this difference? The answer is not obvious. It may partially explain the case of Balasore, which comes at $15^{\text {th }}$ position in the ranking in irrigation, but Bhadrak is in the $4^{\text {th }}$ position. This needs an indepth investigation. The analysis does not observe any clear cut correspondence between RI and CRPNGINT in cases of middle and low RI districts. Most of the districts from Western Odisha, viz. Sambalpur, Sonepur, Baragarh, Boudh, etc. are in the medium RI category but all of them are not ranked in the middle cropping intensity districts. Boudh and Baragarh fall under low cropping intensity districts. Similarly Malkangiri of South Odisha ranks in the low RI districts but in the group of middle cropping intensity. The Maps $1 \& 2$ explains the geographical division of such rankings.

An analysis of correlation shows that CRPNGINT is positively correlated with all types of infrastructure. Out of these it is significant at 1 percent level in cases of Physical and social infrastructure. The correlation between

\footnotetext{
${ }^{2}$ Factor analysis attempts to identify underlying variables, or factors, that explain the pattern of correlations within a set of observed variables. Factor analysis is often used in data reduction, by identifying a small number of factors, which explain most of the variance observed in a much larger number of manifest variables. In the PCA approach the first principal component is that linear combination of items, which explains the maximum of variance across the observation at a point in time.
} 
CRNGINT and RII is seen to be significantly correlated (Table 4). Although the outcomes as reflected in the correlation matrix (Table 4) are in the expected line but they indicate multicollinearity problem in case we fit a regression by taking PII, SII and FII as right hand side variables. The simple regression results are presented in Table 5. It shows that although the $\mathrm{R}^{2}$ values seem to be low numerically, they are significant statistically, except for FII. The slope coefficient is the highest for PII, which shows that physical infrastructure is the leading factor in all categories of infrastructure influencing cropping intensity. If PII improves by one point, then cropping intensity increases by 4.36 percent, one unit rise in SII results in 4.09 percent rise in CRPNGINT and a unit rise in overall infrastructure result in 4.87 percent increase in CRPNGINT. Although not significant at 5\% level, FII is significant at 10 percent level.

However, the low value of $\mathrm{R}^{2}$ also gives an indication that there are several other factors which have not been taken in the model. Finding those factors is another research matter per se. Without those services like irrigation, electricity, road, education, primary health, etc. are unable to explain the variation in CRPNGINT. However, in search of an answer I tried to verify the descriptive statistics of the selected indices, summary of which is presented in Table 6. It is observable that the coefficient of variation in CRPNGINT is very low in comparison to that of infrastructure indices. This may be a reason why $\mathrm{R}^{2}$ is small but significant. Variability is the highest in case of FII and the lowest in SII.

\section{Tables And Graphs}

Table 1 Categorisation of Rural Infrastructure

\begin{tabular}{|c|c|c|c|}
\hline Categories of infrastructure & Facilities Taken & Variables taken & $\begin{array}{l}\text { Abbreviation } \\
\text { Of variables }\end{array}$ \\
\hline Physical & $\begin{array}{l}\text { Irrigation } \\
\text { Electricity } \\
\text { Transport } \\
\text { Communication }\end{array}$ & $\begin{array}{l}\text { Percentage of gross irrigated area to gross } \\
\text { cropped area } \\
\text { Percentage of rural households with electricity } \\
\text { connection } \\
\text { Density of rural roads per thousand hectare of } \\
\text { net sown area } \\
\text { Percentage of rural household with telephone } \\
\text { connection }\end{array}$ & $\begin{array}{l}\text { PGIA } \\
\text { PHHELCT } \\
\text { RURDEN } \\
\text { PHHTELCN }\end{array}$ \\
\hline Social & $\begin{array}{l}\text { Education } \\
\text { Health } \\
\text { Housing } \\
\text { Amenities }\end{array}$ & $\begin{array}{l}\text { Rural literacy rate } \\
\text { Beds in rural allopathic hospitals per lakh of } \\
\text { rural population } \\
\text { Percentage of rural good houses to rural total } \\
\text { houses } \\
\text { Percentage of rural household with latrine }\end{array}$ & $\begin{array}{l}\text { RURALIT } \\
\text { BDHOSP } \\
\text { PGDHOUSE } \\
\text { PHHLATRN }\end{array}$ \\
\hline Financial & $\begin{array}{l}\text { Banking } \\
\text { Credit } \\
\text { Marketing }\end{array}$ & $\begin{array}{l}\text { Percentage of rural households availing } \\
\text { banking services. } \\
\text { Credit per operational holding given by } \\
\text { Agricultural Credit Co-operative Societies } \\
\text { Marketing co-operative societies per lakh of } \\
\text { operational holdings }\end{array}$ & $\begin{array}{l}\text { BNKSER } \\
\text { AGCREDIT } \\
\text { MKTGSOC }\end{array}$ \\
\hline
\end{tabular}

Weighting method: Principal Component Analysis (PCA)

Table 2. District-wise Infrastructure Indices

\begin{tabular}{|c|c|c|c|c|c|c|c|c|c|c|c|}
\hline S.N & District & PII & SII & FII & RII & S.N & District & PII & SII & FII & RII \\
\hline 1 & Anugul & 6.434 & 8.214 & 3.715 & 16.882 & 16 & Kandhamala & 2.335 & 4.922 & 0.741 & 7.389 \\
\hline 2 & Balasore & 6.562 & 8.836 & 3.879 & 17.717 & 17 & Kendrapara & 6.818 & 8.09 & 2.549 & 16.126 \\
\hline 3 & Baragarh & 6.356 & 6.237 & 3.906 & 15.153 & 18 & Keonjhar & 3.819 & 5.78 & 1.571 & 10.305 \\
\hline 4 & Bhadrak & 7.299 & 8.174 & 3.334 & 17.338 & 19 & Khurda & 9.671 & 9.713 & 5.901 & 23.225 \\
\hline 5 & Bolangir & 2.833 & 5.721 & 2.396 & 10.025 & 20 & Koraput & 3.247 & 4.687 & 2.33 & 9.41 \\
\hline 6 & Boudh & 3.783 & 6.486 & 2.05 & 11.334 & 21 & Malkangiri & 2.933 & 2.044 & 2.288 & 6.644 \\
\hline 7 & Cuttack & 8.438 & 10.172 & 7.418 & 23.785 & 22 & Mayurbhanj & 3.3 & 4.993 & 1.653 & 9.158 \\
\hline 8 & Deogarh & 1.948 & 3.898 & 1.425 & 6.67 & 23 & Nawarangpur & 1.688 & 4.432 & 2.127 & 7.518 \\
\hline 9 & Dhenkanal & 5.588 & 7.844 & 3.487 & 15.539 & 24 & Nayagarh & 5.202 & 9.762 & 4.396 & 17.722 \\
\hline 10 & Gajapati & 3.43 & 4.8 & 2.66 & 9.974 & 25 & Nuapada & 2.822 & 4.149 & 0.841 & 7.227 \\
\hline 11 & Ganjam & 7.257 & 9.568 & 4.64 & 19.708 & 26 & Puri & 8.092 & 9.077 & 1.977 & 17.752 \\
\hline 12 & Jagatsingpur & 7.011 & 9.195 & 3.248 & 17.93 & 27 & Rayagada & 3.431 & 3.546 & 1.802 & 8.081 \\
\hline 13 & Jajpur & 7.81 & 10.233 & 3.172 & 19.578 & 28 & Sambalpur & 6.183 & 5.423 & 3.425 & 13.825 \\
\hline 14 & Jharsugura & 5.048 & 7.275 & 2.827 & 13.933 & 29 & Sonepur & 5.33 & 5.296 & 4.387 & 13.727 \\
\hline 15 & Kalahandi & 3.234 & 5.156 & 1.364 & 8.996 & 30 & Sundargarh & 4.411 & 5.658 & 4.129 & 12.964 \\
\hline
\end{tabular}

Source: Author's own computation by using SPSS 
Table 3 Positions of Districts in Cropping Intensity vis-à-vis Rural Infrastructure

\begin{tabular}{|c|c|c|c|c|c|c|c|}
\hline \multirow[b]{2}{*}{ District } & \multicolumn{3}{|c|}{ Rank in } & \multirow[b]{2}{*}{ RII } & \multirow{2}{*}{$\begin{array}{c}\text { Rank in } \\
\text { RII }\end{array}$} & \multirow[b]{2}{*}{ CRPNGINT } & \multirow{2}{*}{$\begin{array}{c}\text { Rank in } \\
\text { CRPNGINT }\end{array}$} \\
\hline & PII & SII & FII & & & & \\
\hline Anugul & 10 & 9 & 9 & 16.88 & 10 & 162.31 & 10 \\
\hline Balasore & 9 & 8 & 8 & 17.72 & 8 & 139.60 & 22 \\
\hline Baragarh & 11 & 15 & 7 & 15.15 & 13 & 131.95 & 26 \\
\hline Bhadrak & 5 & 10 & 12 & 17.34 & 9 & 128.93 & 28 \\
\hline Bolangir & 26 & 17 & 18 & 10.03 & 20 & 130.09 & 27 \\
\hline Boudh & 19 & 14 & 22 & 11.33 & 18 & 142.24 & 21 \\
\hline Cuttack & 2 & 2 & 1 & 23.78 & 1 & 186.49 & 2 \\
\hline Deogarh & 29 & 28 & 27 & 6.67 & 29 & 161.26 & 12 \\
\hline Dhenkanal & 13 & 12 & 10 & 15.54 & 12 & 160.63 & 14 \\
\hline Gajapati & 21 & 24 & 16 & 9.97 & 21 & 167.63 & 8 \\
\hline Ganjam & 6 & 5 & 3 & 19.71 & 3 & 183.37 & 3 \\
\hline Jagatsingpur & 7 & 6 & 13 & 17.93 & 5 & 182.64 & 4 \\
\hline Jajpur & 4 & 1 & 14 & 19.58 & 4 & 179.58 & 5 \\
\hline Jharsugura & 16 & 13 & 15 & 13.93 & 14 & 139.13 & 23 \\
\hline Kalahandi & 24 & 21 & 28 & 9.00 & 24 & 150.57 & 17 \\
\hline Kandhamala & 28 & 23 & 30 & 7.39 & 27 & 146.66 & 19 \\
\hline Kendrapara & 8 & 11 & 17 & 16.13 & 11 & 172.67 & 6 \\
\hline Keonjhar & 18 & 16 & 26 & 10.30 & 19 & 145.85 & 20 \\
\hline Khurda & 1 & 4 & 2 & 23.23 & 2 & 165.16 & 9 \\
\hline Koraput & 23 & 25 & 19 & 9.41 & 22 & 135.18 & 25 \\
\hline Malkangiri & 25 & 30 & 20 & 6.64 & 30 & 158.49 & 15 \\
\hline Mayurbhanj & 22 & 22 & 25 & 9.16 & 23 & 122.85 & 30 \\
\hline Nawarangpur & 30 & 26 & 21 & 7.52 & 26 & 138.88 & 24 \\
\hline Nayagarh & 15 & 3 & 4 & 17.72 & 7 & 169.05 & 7 \\
\hline Nuapada & 27 & 27 & 29 & 7.23 & 28 & 153.96 & 16 \\
\hline Puri & 3 & 7 & 23 & 17.75 & 6 & 187.55 & 1 \\
\hline Rayagada & 20 & 29 & 24 & 8.08 & 25 & 162.27 & 11 \\
\hline Sambalpur & 12 & 19 & 11 & 13.82 & 15 & 149.20 & 18 \\
\hline Sonepur & 14 & 20 & 5 & 13.73 & 16 & 160.75 & 13 \\
\hline Sundargarh & 17 & 18 & 6 & 12.96 & 17 & 124.26 & 29 \\
\hline
\end{tabular}

Source: Author's own calculation from various data sources

Table 4. Correlations

\begin{tabular}{|ll|r|r|r|r|r|}
\hline & & CRPNGINT & \multicolumn{1}{c|}{ PII } & \multicolumn{1}{l|}{ SII } & \multicolumn{1}{l|}{ FII } & \multicolumn{2}{l|}{ RII } \\
\hline Pearson & CRPNGINT & 1.000 & $.494^{* *}$ & $.487^{* *}$ & .315 & $.488^{* *}$ \\
Correlation & PII & $.494^{* *}$ & 1.000 & $.859^{* *}$ & $.731^{* *}$ & $.959^{* *}$ \\
& SII & $.487^{* *}$ & $.859^{* *}$ & 1.000 & $.648^{* *}$ & $.939^{* *}$ \\
& FII & .315 & $.731^{* *}$ & $.648^{* *}$ & 1.000 & $.828^{* *}$ \\
& RII & $.488^{* *}$ & $.959^{* *}$ & $.939^{* *}$ & $.828^{* *}$ & 1.000 \\
\hline
\end{tabular}

**. Correlation is significant at the 0.01 level (2-tailed).

Table 5. Regression results

\begin{tabular}{|l|l|l|l|l|l|}
\hline Model & Regressor & Intercept & Slope & p-value of & $\mathrm{R}^{2}$ \\
\hline A & PII & 132.5 & 4.36 & 0.006 & 0.244 \\
\hline B & SII & 127.5 & 4.085 & 0.006 & 0.237 \\
\hline C & FII & 142.5 & 4.07 & 0.09 & 0.099 \\
\hline D & RII & 129.4 & 4.87 & 0.006 & 0.238 \\
\hline
\end{tabular}

Dependent variable: CRPNGINT, $\mathrm{n}=30$ 
Table 6. Descriptive Statistics

\begin{tabular}{|l|r|r|r|}
\hline \multicolumn{1}{|c|}{ Indices } & \multicolumn{1}{|c|}{ Mean } & $\begin{array}{l}\text { Standard } \\
\text { Deviation }\end{array}$ & $\begin{array}{l}\text { Coefficient } \\
\text { of Variation }\end{array}$ \\
\hline PII & 5.08 & 2.16 & 42.53 \\
SII & 6.65 & 2.27 & 34.17 \\
FII & 2.99 & 1.47 & 49.36 \\
RII & 13.52 & 4.98 & 36.86 \\
CRPNGINT & 154.64 & 19.06 & 12.33 \\
& & & \\
\hline
\end{tabular}

Map 1. Disparity in Rural Infrastructure Development in Orissa

Map 2 Cropping Intensity in Orissa

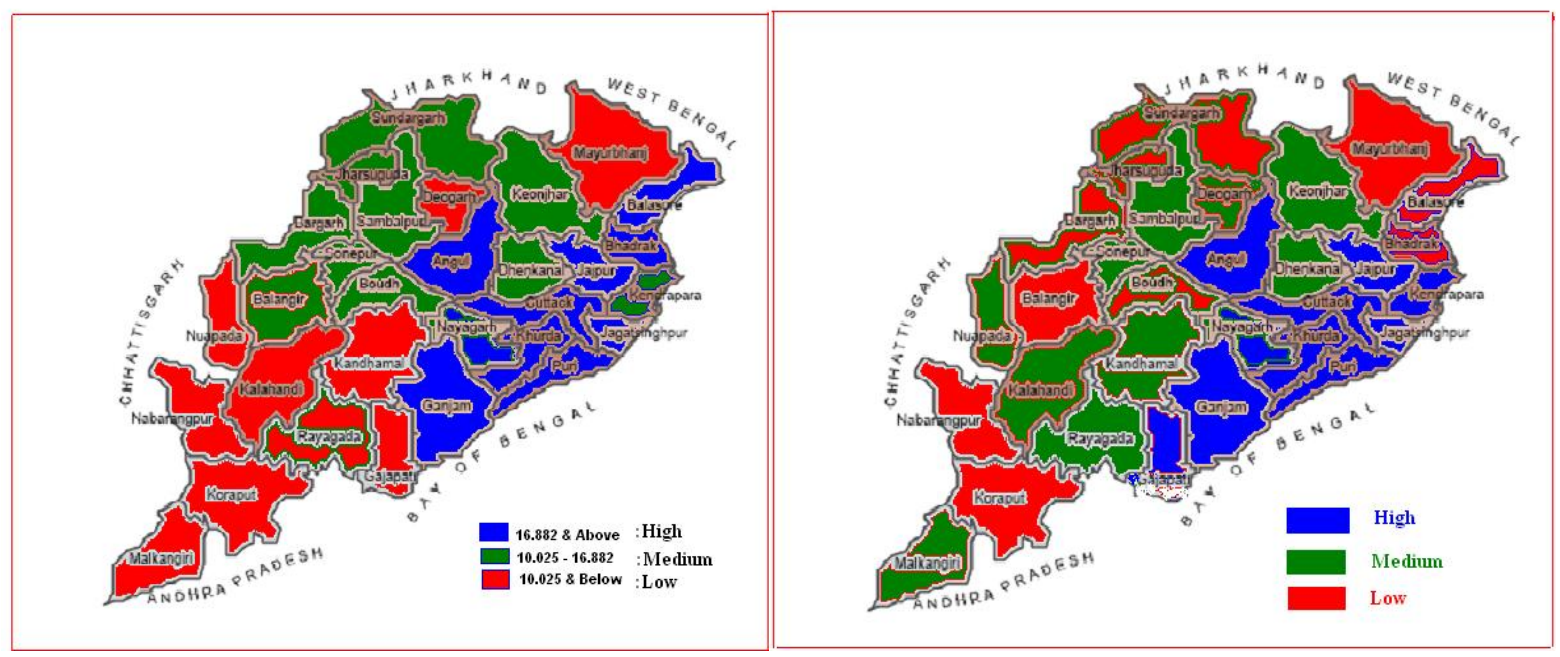

\section{Summary And Findings}

The study finds several crucial outcomes that (i) there is regional disparity in the development of rural infrastructure in Odisha. The coastal region is ahead of Western and Southern parts of the state in terms of the stock of infrastructure, (ii) regional disparity is lesser in cropping intensity, (iii) infrastructure has a significant impact on cropping intensity in agriculture. Out of the three categories of infrastructure, physical infrastructure has an edge over social and financial infrastructure.

However, despite the eleven services in the preparation of different indices for infrastructure, the $\mathrm{R}^{2}$ values of the regression are less that 0.3 (although statistically significant). It may be due to the scope for high prevalence of error terms in a two variable model, less variability in the dependent variable (CRPNGINT) or exclusion of any other significant regressor. All these may be addressed in a further study.

\section{Acknowledgement}

This article was presented at the Golden Jubilee Conference of the Indian Econometric Society (TIES) held at IGIDR, Mumbai. The author likes to thank the delegates whose comments helped in its improvement. Usual disclaimers apply.

\section{References}

[1] Chittaranjan Nayak, Physical infrastructure and land productivity: a district level analysis of rural Orissa, ICFAI Journal of Infrastructure, Icfai University Press, Hyderabad, 6(3), 2008, 7-21

[2] International Fund for Agricultural Development, Making a difference in Asia and pacific, News Letter, Issue 20, March-April 2008, Bangladesh

[3] Asian Development Bank, "Vietnam: Rural Infrastructure Sector Project", Reference Number, Project Number: 29529. September 2010

[4] National Council of Applied Economic Research, India Rural Infrastructure Report, New Delhi, 2003

[5] S S Sangwan, Infrastructure for Agricultural Development, Occasional Paper, no. 53, Department of Economic Analysis Research, NABARD, Mumbai, 2010 